\title{
Formation of optimal private involvement in urban rail public-private partnership projects in China
}

\author{
Yongjian Ke \\ School of Built Environment, \\ University of Technology Sydney, \\ Ultimo NSW 2007, Australia \\ Email: Yongjian.Ke@uts.edu.au
}

\begin{abstract}
Subnational governments in China are suffering from urgent urban development demands and severe fiscal pressure, public-private partnerships (PPPs) are hence strongly promoted to attract private investors to participate in the development and operation of urban rail projects. However, there is no formal assessment to determine the degree of private involvement in a PPP project. This question is more critical in the sector of urban rail, in which the huge investment cannot rely on the private sector alone. This study hence aimed to develop a five-stage systematic procedural framework to determine the optimal private involvement in an urban rail PPP project in China. The findings add to the current knowledge base by summarising an appropriate and systematic procedural framework for the allocation of involvement in a PPP project. They are also beneficial for the industry practitioners as a management framework to determine the appropriateness of private involvement.
\end{abstract}

Keywords: private involvement; procedural framework; procurement; public-private partnership; PPP; urban rail; China.

Reference to this paper should be made as follows: Ke, Y. (2018) 'Formation of optimal private involvement in urban rail public-private partnership projects in China', Int. J. Project Organisation and Management, Vol. 10, No. 3, pp.268-286.

Biographical notes: Yongjian Ke is a Senior Lecturer in Project Management in the School of Built Environment at the University of Technology Sydney. His current research interests include risk management, procurement management and relationship management in mega projects.

\section{Introduction}

On the executive meeting of the State Council on 31 July 2013, Premier Keqiang Li stated that the government would continue to support the private investment in the infrastructure development. The central government also claimed to further widen the market access of public services to eligible private investors with sound credit. Stepping into the year of 2014, which was considered as one of the very important years for public-private partnership (PPP) in China, the Ministry of Finance (MOF) and National Development and Reform Commission (NDRC) have been extraordinarily active in promoting and leading the development of PPP. In December 2014, the MOF issue several important documents including 'Operational Guidelines for PPPs (Trial 
Implementation)' and 'Guidelines for PPP Contract (Trial Implementation)'. At the same time, the NDRC also published their version of operational guidelines and contract guidelines. These newly issued regulations show the ongoing positive attitude of the central government. It is therefore expected to see more private involvement in infrastructure development in China via PPP mode (Cheng et al., 2016).

According to China's 13th Five-Year Plan (Xinhuanet, 2016), China will increase the government's focus on innovation - with particular emphasis on infrastructure development in order to respond to the rising urbanisation. The government is expected to continuously promote the development of public transportation to relieve traffic jams and enhance mobility for urban commuters. Urban rail transportation is one of the priorities. It was claimed that the central government will build 3,000 kilometres of new urban rail lines during the 13th five-year (Xinhuanet, 2016). With no doubts, the private investment is strongly encouraged in the development of urban rail projects, which could be seen in several recent projects such as Beijing Metro Lines 14 and 16 (Si et al., 2016).

However, unlike other public facilities such as toll roads or power plants, one of the major challenges of urban rail PPP projects is the huge investment, which makes it impossible for the private investors to obtain a reasonable rate of investment return from the expected revenues, thereby creating a financial gap. The financial gap needs to be closed with funds from the public sector. In this case, the public sector hence has to inject a large share of investment in an urban rail PPP project to attract private investors (Sharma et al., 2010). Although effective partnerships develop from shared interests, responsibilities and resources between the public and private sectors in a PPP project (Ke et al., 2010a, 2010b), there is potential for conflicts of interests. In order to better deliver urban rail PPP projects and protect public interests, this paper discusses the issue of private involvement with the aim of developing a procedural framework to determine the optimal private involvement in an urban rail PPP project in China.

The term 'private involvement' in this paper has two-fold definitions. First, it refers to the share of investment (including both debt and equity) by the private sector, following Sharma et al. (2010). In China, subnational governments particularly value this meaning, especially the share of initial investment by the private sector; second, it also denotes a more comprehensive concept including responsibilities, obligations and risks undertaken, as well as resources and skills committed to a project by the private sector, following Jasiukevičius and Vasiliauskaitè (2012).

The paper is structured as follows: an overview of the literature regarding PPPs in China and private involvement is presented, followed by a section describing the design methodology. The influencing factors are briefly introduced in the following section, based on which is a procedural framework to determine the optimal private involvement. The five-stage systematic framework is then further elaborated in detail. Concluding comments and limitations of the research together with opportunities for further research conclude the work.

\section{Literature review}

\subsection{PPP practice and research in China}

The Shajiao B power plant project in Guangdong province was the first implementation of PPPs in China (Cheng et al., 2016). After 1996, the central government awarded 
several state-approved pilot build-operate-transfer (BOT) projects to promote BOT on a larger scale. Thereafter, the involvement of private investors in infrastructure development grew rapidly, but fad out gradually at the end of the 1990s due to the Financial Crisis in Asia. Along with the continued rapid economic growth in China when stepping into the 21 st century, the shortage of infrastructure imposed budgetary pressures on subnational governments and led to the second boom of private investment. Since late 2013, the strong encouraging message from the central government has led to another boom of private investment in public projects after 2014 (Cheng et al., 2016).

Along with the implementations of PPPs in China, there is increasing attention in the topic of PPPs in China, not only in international journals but also in domestic Chinese journals (Ke et al., 2009; Zhang et al., 2016). According to a statistical analysis of PPP publications by Ke et al. (2009), PPP papers published around 2000 can be categorised into three groups namely 'risk', 'procurement' and 'financial'. New ideas and topics had been introduced in the publications after 2000, including:

a investment environment

b procurement

c economics viability

d financial package

e risk allocation and management

$\mathrm{f}$ governance issue

g other integration research (Ke et al., 2009).

In recent publications, the research topics have been switched from a pure construction perspective to a combination of topics on finance, law, public administration, construction and management. Current research topics published in the academic journals include:

a selection of financing models

b optimisation of financial structure

c risk allocation and management

d regulatory and institutional frameworks

e behaviours of both sectors

f determination of concession period

g contract structure and key clauses

$\mathrm{h}$ evaluation of private partners

i performance indicators

j price mechanism (Zhang et al., 2016). 


\subsection{PPP research in urban rail transportation in China}

Publications on the topic of urban rail transportation published by international scholars in international journals have been frequently seen, such as Hayashi (1989), Simpson (1990) and Wilmoth (1990). However, it is rare to read academic articles in international journals on the topic of PPP in urban rail transportation in China, especially published by researchers from Mainland China. To the best of authors' knowledge, Yuan et al. (2010) identified 15 driving factors associated with PPP projects in metropolitan transportation systems from the perspective of Chinese public sector; de Jong et al. (2010) studies seven urban rail PPP projects in five large metropolitan areas in China; Roumboutsos et al. (2013) evaluated the experience of PPPs in China's urban rail development with the focus on critical factors impacting on the project viability based on the case study of Beijing Metro Line 4; Chang (2013) also studied the Beijing Metro Line 4 to illustrate benefits, costs, opportunities and risks in PPPs in China, and he later studied the Beijing metro financing sustainability to demonstrate how subnational governments finance the investment in metro systems (Chang, 2014).

\subsection{Private involvement in PPPS}

The huge investment in an urban rail PPP project cannot rely on the private sector alone, which then requires public fiscal exposure. It is hence a critical question how to determine the private involvement. Unfortunately, there are not many research efforts to handle this issue. Sharma et al. (2010) presented a structured approach to determine the debt-equity investment between public and private sectors in PPP projects, which took into account financial factors alone. Jasiukevičius and Vasiliauskaitè (2012) formed a procedural model to evaluate the requirements for private sector's involvement in the delivery of public services, which is rather practical and focuses more on 'how' than 'why'. Albalate et al. (2013) found that risk associated with cost recovery and relative cost of labour are key factors explaining the extent of private involvement.

Publications that consider the targets or rules limiting fiscal exposure could provide a valuable reference to the research question in this paper to some extent. For instances, Irwin (2007) described an approach for governments to control spending commitments in PPPs; Peru's Legislative Decree No. 1012 (which approves the framework law for PPP and its regulations) also states that the present value of total fiscal commitments to PPPs shall not exceed 7\% of GDP (Peru, 2008); Liu and Pradelli (2012) provided another alternative that is to incorporate limits on PPP commitments within other fiscal targets like public debt. However, the above publications or government documents discussing the limits for fiscal exposure are mainly suitable in the situation where the private sector can undertake the PPP project financially, while the public sector is looking for some extent of involvement in order to achieve the best project performance.

\section{Research methodology}

As part of a comprehensive research into PPP implementation in urban rail PPP projects in China, multiple research methods, including content analysis, case study and focus group discussion were adopted to identify seven types of factors influencing the private 
involvement, including project financial model, government fiscal commitment, risk allocation, public accountability, efficiency considerations, policy and regulations, and organisational marketing strategies. This paper will briefly introduce these influencing factors in the following section and mainly present a procedural framework based on these influencing factors to determine the optimal private involvement.

The development of a procedural framework is based on the explanatory paradigm, i.e., this research aims at describing, explaining and predicting in order to understand the formation problem of optimal private involvement. However, understanding alone is not enough. The ultimate mission is to develop design knowledge, i.e., knowledge that can be used in designing solutions to problems in the field in question (Aken, 2004). The development of a procedural framework in this paper is considered as a process-design, i.e., the authors' own subjective plan for the problem-solving cycle. According to Aken (2004), this type of process-design is of a heuristic nature, which can rather be described as 'if you want to achieve $\mathrm{Y}$ in situation $\mathrm{Z}$, then something like action $\mathrm{X}$ will help'. 'Something like action $X$ ' is a general prescription which has to be translated to the specific problem at hand; in solving that problem, one has to design a specific variant of action X. But the indeterminate and heuristic nature makes it impossible to provide proof. To use the procedural framework for an application or for further research, readers need evidence to forecast the effectiveness of the framework and for translation into the new context. This is hence considered as one of the limitations of this paper.

\section{Influencing factors}

The influence of project financial model is straightforward and has been well reported in the literature, such as Sharma et al. (2010). In the sector of urban rail, there is generally a minimum investment by the public sector, i.e., a maximum investment by the private sector so as to achieve a reasonable rate of investment return. In the case of Beijing Metro Line 4, the private sector is responsible for the financing of part B (30\% of total initial investment). Once the financial model is established and the private investor's expected rate of investment return is assumed, the share of private investment could be calculated.

Government fiscal commitment, including initial investment, ongoing payment and overall fiscal budget and balance, is significant to determine the private involvement (Roumboutsos et al., 2013). Among them, initial investment and ongoing payment by the public sector are actually included in the project financial model. Overall fiscal budget and balance is the fundamental factor that determines the government capability for initial investment and ongoing payment, thereby influencing the share of private investment.

The arrangement to share or undertake risks by the private sector is included in the definition of private involvement. Risk allocation has been commonly seen in recent publications, such as Ke et al. (2010b, 2013). A general principle is that each risk should be allocated to the party best able to manage it at the least cost (Cooper et al., 2005). Such ability to manage risks may include whether the party is able to foresee the risk, whether the party is able to assess the possible magnitude of consequences of the risk, 
whether the party is able to control the risk chance of occurring, whether the party is able to manage the risk in case of occurring, and whether the party is able to sustain the consequences if the risk occurs (Lam et al., 2007).

PPPs change the dynamics of public accountability by involving private partners in government decision making and program delivery (Forrer et al., 2010). The terms and conditions of private involvement deserve careful scrutiny and understanding by public officials, as private partners enter into a PPP project for different reasons than governments such as pursuing profits (Chan et al., 2009). In the sector of urban rail projects, accountability requirements are complicated, because government responsibilities are shared with the private partners and this horizontal relationship between the public and private sectors may cause many contemporary challenges.

The concept of adopting PPPs to improve the efficiency in delivering public services is in fact not fresh in many countries such as Australia (Infrastructure Australia, 2008), but not given sufficient attention in China yet (Cheng et al., 2016). Under the severe fiscal pressure, the major driving force for most subnational governments to choose PPPs over traditional procurement is still economy-related (Chan et al., 2009). Nevertheless, as a straightforward principle, tasks in that the private sector has a more efficient capability should be allocated to the private.

In China, there is no formal process for deciding the type and extent of government support for PPPs, nor the private involvement. However, there are some particular regulations that may influence the private involvement to some extent. Taking Beijing for instance, Beijing Municipal Commission of Development and Reform (2013) prescribes a concession period of 30 years and an expected return on investment of $8 \%$ for private investors. A reasonable share of private investment could be calculated using these prescribed economic conditions.

For private investors, it is important to maintain a good relationship with the subnational governments and a good track record of past performance in order to grasp a share of the PPP market. Ke et al. (2015) proved that organisational marketing strategies towards relational contracting have a positive impact on the project outcomes, especially client satisfaction and relationship quality among contracting parties. In other words, different organisational marketing strategies could lead to different decisions on the private involvement in a PPP project.

\section{Five-stage systematic framework}

The formation of the private involvement in an urban rail PPP project is important to project success, as it may arise possible problems related with the role of each party and apportionment of risks, liabilities and rewards between partners (Jasiukevičius and Vasiliauskaite, 2012). However, very few information was disclosed in the PPP literature yet. In light of the above-mentioned influencing factors, this paper will present a five-stage systematic framework in Figure 1 by systemising various literature by Jasiukevičius and Vasiliauskaitè (2012), Ke et al. (2010b), Sharma et al. (2010), Zhang (2005), Zhang and Chen (2013). 
Figure 1 Five-stage framework for formation of optimal private involvement in urban rail PPP projects

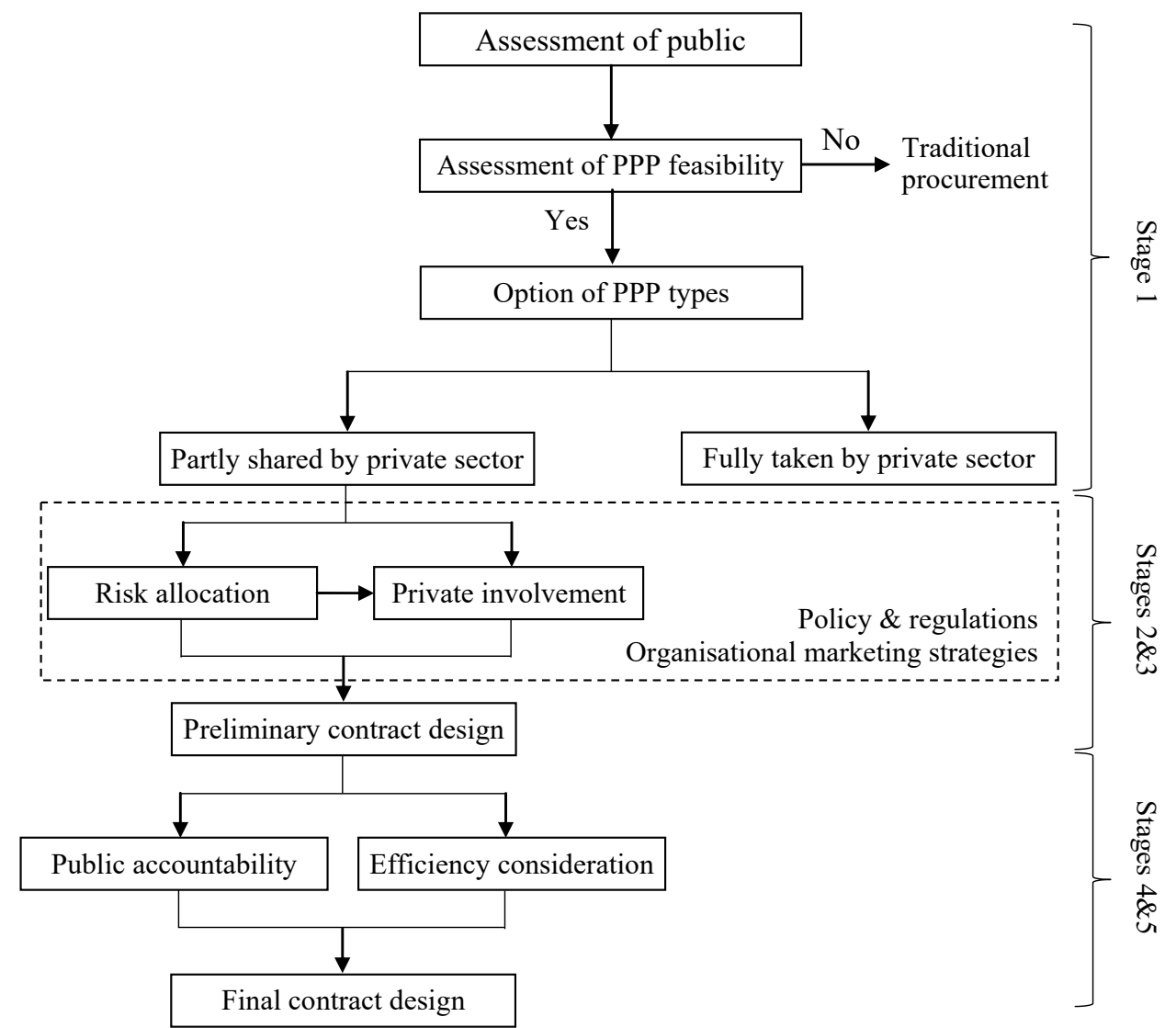

The process of optimal private involvement formation firstly starts from the assessment whether to deliver the urban rail project via PPP. In the second and third stages, the public and private sectors determine the risk allocation and calculate the amount and plan of private investment under the conditions of organisational marketing strategies and policy and regulations. In these two stages, project financial model, government fiscal commitment, risk allocation, policy and regulations, and organisational marketing strategies are considered. The output of the second and third stages is the preliminary design of concession contract defining the share of investment, responsibilities, obligations, risks undertaken, resources and skills committed to the project. In stages four and five, the requirements for public accountability and efficiency consideration are validated to ensure that private involvement in an urban rail project would not become a detrimental action to the public interests. 


\subsection{Assessment of PPP feasibility}

It has been practiced in many mature PPP markets such as the UK and Australia, when choosing a delivery method, the government needs to compare the chosen PPP model with a public sector comparator to demonstrate value for money (VFM) and enhance the partnership evaluation (Zhang and Chen, 2013). However, this quantitative assessment was recently reinforced in the Guide on Operation of PPP Projects (interim) issued by the MOF in November 2014, which also requires a quantitative assessment of public liabilities of subnational governments over the project life cycle. The MOF issued a Guide on Evaluation of VFM in PPP projects (interim) in December 2015, which was updated in October 2016.

Figure 2 Assessment of PPP feasibility

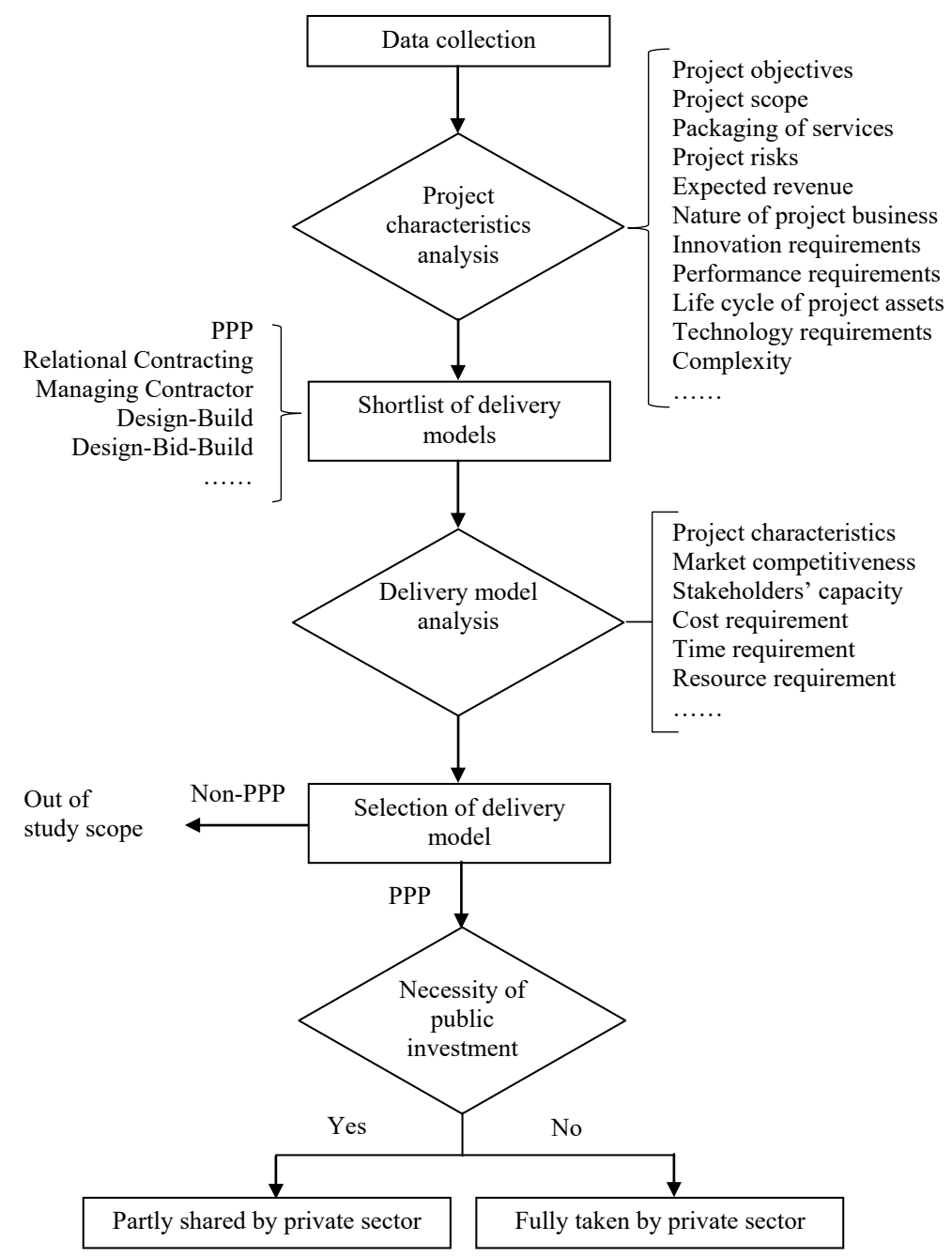


Before the issuance of MOF's guide, there were no mechanisms for VFM assessments or other decision-making frameworks to ensure that PPP is the most appropriate option. Because of the immense budgetary pressure on the governments to provide infrastructure, the concerns regarding efficiency in project procurement and delivery as well as specific conditions of the target project are often ignored (Cheng et al., 2016). The certain extent of blindness in selecting PPP projects was regarded as one of the reasons why many PPP projects have failed (Wang, 2014).

After the issuance of MOF's guide, due to the shortage of data and skills to enable such quantitative assessment, there is still some way to go until a coherent regulatory environment is realised and can be enforced (Economist Intelligence Unit, 2015). A strong evidence is the spectacular number of PPP projects, 10,471 projects as of September 2016, in the project database of the MOF, only 946 of which have entered the implementation stages (China Public-Private Partnerships Center, 2016). Identifying VFM and bringing it to life remain challenging even in countries with long experience with PPPs such as the UK (IISD, 2015). Therefore, in the recommended framework for assessing PPP feasibility as shown in Figure 2, a quantitative VFM assessment is not the core requirement. Instead, a comparative analysis of different delivery models and a qualitative analysis taking into account the project characteristics and market competitiveness are highlighted.

In addition, the government in China is usually bound to invest in an urban rail PPP project in order to improve the financial attractiveness. There is hence a need for a formal process for deciding the type and extent of government support for PPPs, which unfortunately was missing before the MOF's guide. The government officials made a decision based on their own judgments or preferences while the general public and even the professionals and academics have little or no influence on the decision making (Sachs et al., 2007). A decision node is hence proposed at the end of the assessment of PPP feasibility with the purpose of determining the necessity of public investment in the PPP project. Two of the above-mentioned influencing factors, i.e., project financial model and government fiscal commitment, will be taken into account at this decision node, so as to evaluate the public fiscal liability and project commercial capacity, thereby determining whether an initial investment from the government is required.

\subsection{Risk allocation}

Given the comprehensive concept of private involvement including responsibilities, obligations and risks undertaken, as well as resources and skills committed to a project by the private sector, it is straightforward that risk allocation should be one of the necessary procedures to determine the private involvement. Being one of the major drivers for VFM, risk allocation in a PPP project aims to distribute risks to the party who is best able to manage at the least cost (Ke et al., 2010b). An equitable risk allocation scheme hence denotes a clear division of roles and responsibilities among contracting parties. In addition, risk allocation is commonly defined through the contractual documents, which can thus be considered as a trade-off between the private sectors' price for undertaking the work and their willingness to accept the risk allocation scheme (Lam et al., 2007). In the context of urban rail PPP projects, the trade-off can mainly be interpreted by the design of price and adjustment mechanisms. In summary, a framework to allocate risks is demonstrated in Figure 3. The proposed risk allocation framework has two stages, i.e., to revise the preferred risk allocation and to design the price and adjustment mechanisms. 
Figure 3 Risk allocation

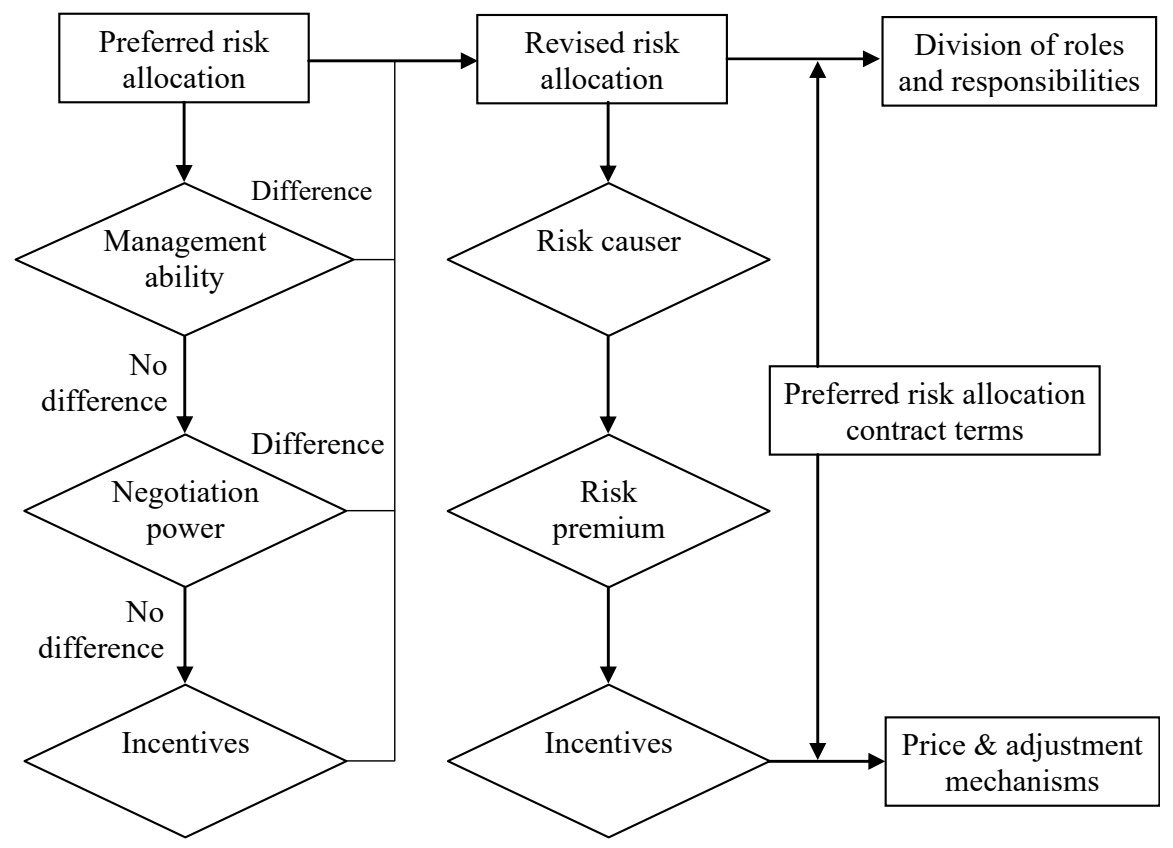

Because there is currently no formal risk allocation scheme example from the government, the first stage starts with a preferred risk allocation scheme from findings on the topic of risk allocation in China's PPP projects, such as Ke et al. (2010b, 2011, 2013). The preferred risk allocation scheme is adopted as the basis to determine the revised allocation based on the specific project characteristics as per the following steps:

a To examine whether the public and private sectors have a significant difference in risk management ability. If there is a significant difference, it is then recommended to allocate the risk to the party that is better able to manage and enter the second stage.

b Else, to examine whether both parties have a significant difference in negotiation power. If there is a significant difference, it is then recommended to allocate the risk to the party that has a weaker negotiation power in order to foster the procurement process and enter the second stage.

c Else, to examine whether the government is willing to the undertake the risk. If the government decides to offer the incentive, it is then recommended to allocate the risk to the government and enter the second stage.

The output of the first stage is a set of revised risk allocation. It is certain that risks are allocated to the party better able to manage, if there is a significant difference in risk management ability.

Roles and responsibilities are then divided based on the revised risk allocation and preferred risk allocation contract terms. The purpose of the second stage is to investigate the fundamental factors for the design of price and adjustment mechanisms as per the following steps: 
a To examine whether the risk taker is the risk causer. It is recommended that risk taker if being the risk causer could not request for a risk premium of that risk.

b To investigate the risk premium concentrated on the measurement of risks undertaken by non-risk causer.

c To examine whether the government is willing to offer an incentive in terms of pricing.

The output of the second stage is the considerations of fundamental factors for the design of price and adjustment mechanisms.

Figure 4 Calculation of private investment

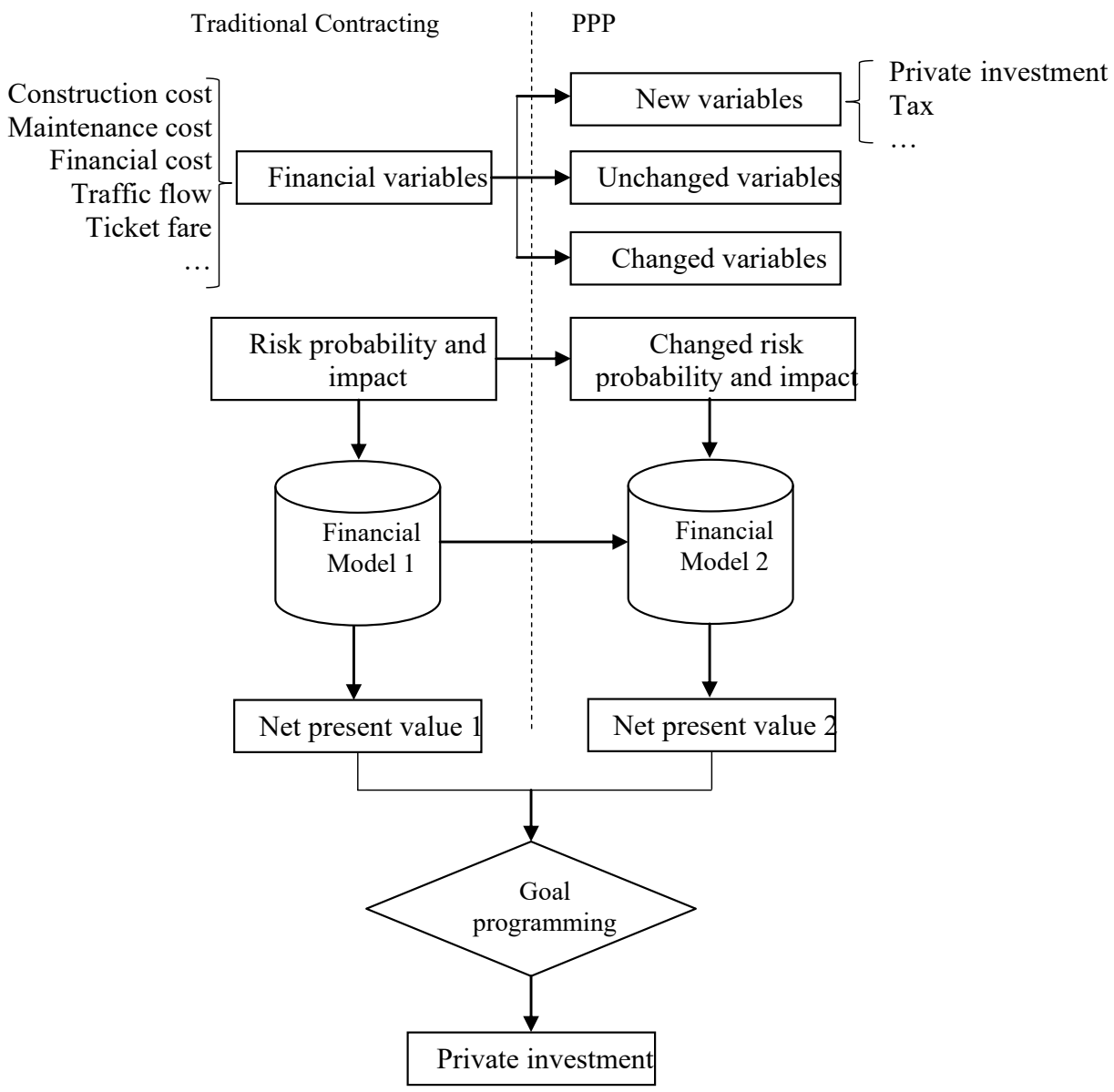

\subsection{Calculation of private investment}

After the identification, evaluation and allocation of risks, it is then possible to calculate the optimal proportion of private investment. This calculation is important to urban rail PPP projects, which generally do not have sufficient profitability for private sectors to invest alone. When assessing the feasibility of PPP in a project, VFM calculation is 
required by the MOF's guide. The financial model 1 shown in Figure 4 using traditional contracting and taking into account risk probability and impact is hence available when calculating the optimal proportion of private investment. The adoption of PPP model would import some changes to the financial model 1 in terms of changes in variables and their risks, in light of which a new financial model 2 can be then obtained. These changes include:

a the property owner changes of several financial variables (e.g., the operation revenue will be taken by the private investors instead of the government)

b the value changes of several financial variables (e.g., the reduced costs of operation and maintenance)

c new financial variables (e.g., the proportion of private investment)

d changes in risk probability and impact associated with financial variables.

Goal programming is recommended to calculate the optimal proportion of private investment in this framework. The goal is set as to obtain the maximum difference in net present value (NPV) of project between traditional contracting and PPP, described as

$$
Z=N P V_{2}-N P V_{1}
$$

where $N P V_{1}$ denotes the net present value under traditional contracting, while $N P V_{2}$ denotes that under PPP. The values of NPV can be calculated by the abovementioned financial models, and approximately described as

$$
N P V=f\left(\text { volume }, \text { price } \operatorname{cost}_{c}, \operatorname{cost}_{f}, \operatorname{cost}_{m}, \operatorname{sub}, \alpha\right)
$$

where

volume traffic flow volume

price ticket fare

cost $t_{c} \quad$ construction cost

cost $_{f}$ financial cost

cost $_{m} \quad$ operation and maintenance cost

sub public fiscal subsidy

$\alpha \quad$ proportion of private investment.

In recognition of the success of Beijing Subway Line 4 project (Chang, 2013, 2014), it could be used as a benchmarking case to calculate the target value of the goal programming. Possible values can then be derived based on different assumptions of private involvement, which lead to two types of deviations including: under-achievement of the goal as represented by negative deviation $\left(d^{-}\right)$and over-achievement of the goal as represented by positive deviation $\left(d^{+}\right)$. To achieve the above-mentioned goal, the achievement function is set as

$$
\min z=f\left(d^{-}\right)
$$

subject to: 
- $D-D S+E_{1}-P_{1}>\gamma E_{2}$ (considering public interests), in which:
$D \quad$ debt
$D S \quad$ debt service
$E_{1} \quad$ private equity
$E_{2} \quad$ public equity
$P_{1} \quad$ profit sharing for private investors
$\gamma \quad$ public opportunity-loss coefficient.

- $D \times D S C R \leq R$ (considering debt capacity constraint), in which:

$D S C R$ debt service coverage ratio

$R \quad$ present value of cash flows.

- $D S_{t} \leq\left(R_{t}-\operatorname{cost}_{m(t)}\right)$ (considering debt service constraint), in which:

cost $_{m(t)}$ operation and maintenance cost at time $t$.

- $D+E_{1}+E_{2} \geq \operatorname{cost}_{c}$ (considering initial project investment).

- $\quad E_{1}-\sum_{t=0}^{T} \frac{P_{1(t)}}{\left(1+i_{p(\min )}\right)^{t}} \leq 0$ (considering project attractiveness), in which:

$T \quad$ concession length

$i_{p(\min )} \quad$ minimum required rate of return for private investor

$P_{1(t)} \quad$ profit sharing for private investors at time $t$.

- $\quad E_{1}-\sum_{t=0}^{T} \frac{P_{1}(t)}{\left(1+i_{p(\max )}\right)^{t}} \leq 0$ (considering capping private return), in which:

$i_{p(\max )} \quad$ maximum required rate of return for private investor.

- price $_{\min } \leq$ price $\leq$ price $_{\max }$ (considering price acceptance), in which:

price $_{\min }$ minimum required ticket fare to maintain project attractiveness

price $_{\max }$ maximum ticket fare accepted by the public.

- $s u b_{\min } \leq s u b \leq s u b_{\max }$ (considering public fiscal capacity), in which:

$s u b_{\min } \quad$ minimum required public subsidy to maintain project attractiveness

$s u b_{\max } \quad$ maximum public subsidy capacity.

\subsection{Public accountability}

The previous two stages of risk allocation and calculation of private investment can determine the private involvement taking into account its twofold definitions considered in this paper, thereby obtaining preliminary contract design. However, because of the nature of PPP projects, it is necessary to conduct a review to guarantee the achievement of public accountability and efficiency improvement. Figure 5 presents a framework for validation of public accountability with the purpose of meeting the requirements of public accountability during the project. Because of the lack of robust project audit mechanisms for PPP projects in China (Cheng et al., 2016), it is hence important to provide relevant indicators and procedures for public accountability in individual PPP contracts. 
Figure 5 Validation of public accountability

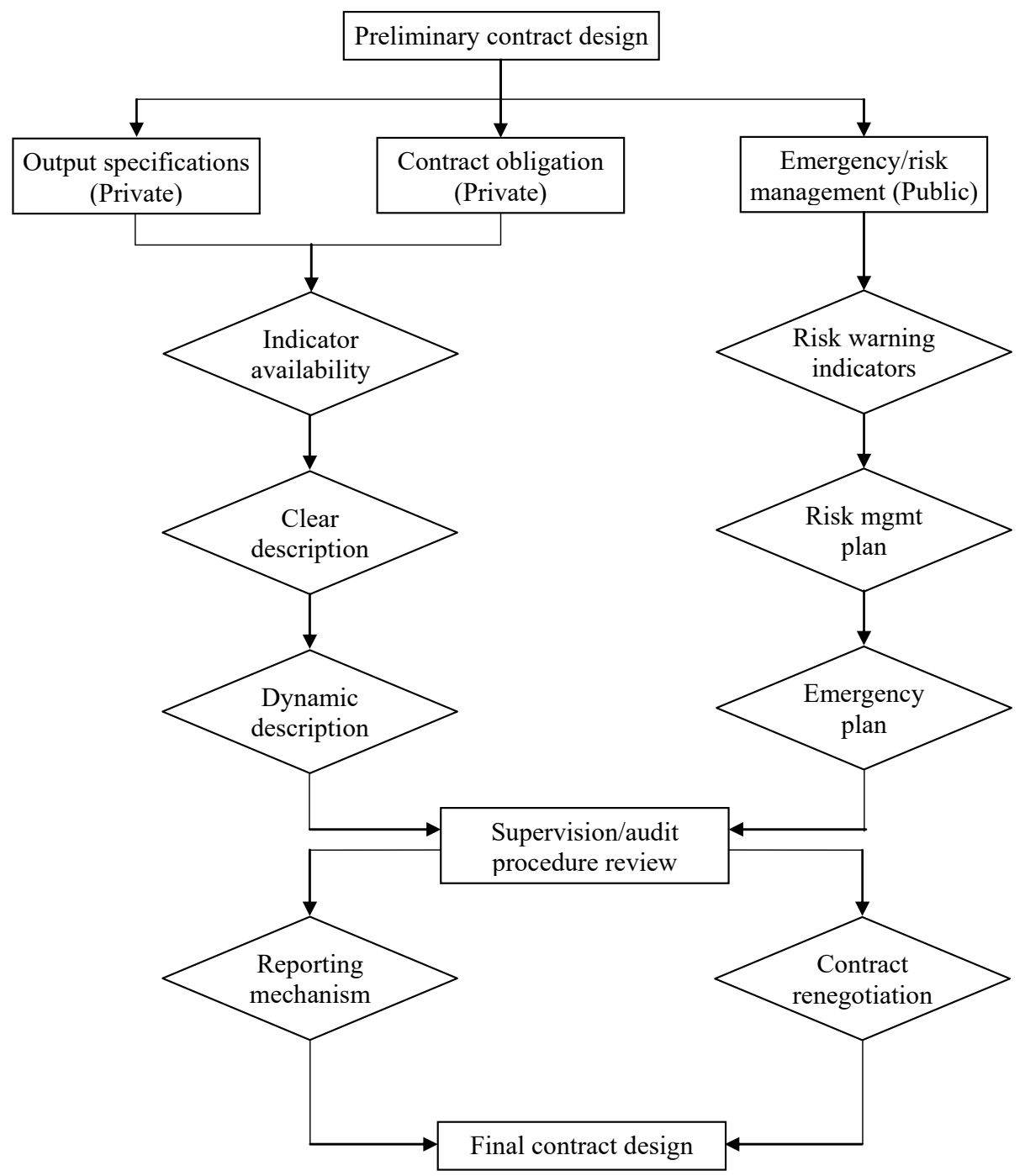

In term of indicators for the private investors, output specifications and contract obligations are highlighted in the framework. In the context of urban rail PPP projects, the output specifications include facilities and assets specifications (e.g., design, construction, operation, and maintenance) and urban rail operation specifications (e.g., ticket fare, traffic flow, train frequency, and safety), while contract obligations designate private investors' roles and responsibilities such as communication management, change management, risk management and relevant operation management to ensure the project success. The framework shown in Figure 5 is then to review and validate whether the above indicators are available with clear and dynamic descriptions.

In term of indicators for the public sector, risk and emergency management is the most important in the context of urban rail PPP projects. This is consistent with the notice from the State Council on the Emergency Response Plan for National Urban Rail 
Transport Operation issued in May 2015. The purpose of public sector indicator design is to meet the management requirements for the government in running an urban rail PPP project, in which emergency management responsibilities are not recommended to be allocated to the private. The first task is to check the availability of risk warning indicators, which are necessary to daily operational monitoring, risk analysis and information reporting. The second task is to validate the availability of risk management plan in order to ensure risks are allocated to the party best able to manage and a long time risk management plan is in place. The third task is to validate the availability of emergency plan so that a management plan is in place to respond to the occurrence of risk events.

In addition, it is imperative to investigate the design of procedures for public accountability in the individual PPP contract with the purpose of meeting public audit requirements. Two key procedures are the reporting mechanism and contract renegotiation mechanism. The purpose of reporting mechanism is to meet the information disclosure requirements for the general public as well as the performance review requirements during and after the concession period (Michalski-Karl et al., 2009). Contract renegotiation may be necessary to improve the performance of the partnership due to the inevitable incompleteness of concession contracts for a long-term PPP project (Cruz et al., 2015). Therefore, the second key procedure recommended is the contract renegotiation mechanism, which aims to offer flexibility for the public and private sectors to make necessary adjustments as per the outcome of public accountability.

\subsection{Efficiency consideration}

A study conducted by Chan et al. (2009) on drivers of adopting PPPs found that respondents from China rated economy-related drivers higher, indicating that government agencies may neglect the significance of efficiency improvement in structuring PPP agreement. Therefore, a framework for validation of efficiency consideration with the purpose of meeting the requirements of efficiency improvement during the project is proposed as shown in Figure 6. The improvement of efficiency resulted from the participation of private sectors in an urban rail PPP project could contribute to the goal of reducing life-cycle costs.

The validation framework for efficiency improvement includes two parts, i.e., qualitative and quantitative efficiency check.

The quantitative efficiency check aims to ensure that the involvement of private sectors in an urban rail PPP project will lead to an improved value for money. Compared to the traditional procurement method, the involvement of private sector in a PPP project brings in many changes to the financial model, such as an increase of participation/procurement cost and a reduction of total project cost including financial service cost, operational cost, labour cost due to less employment positions, etc. (Chan et al., 2009; Chan et al., 2010). The important step in the quantitative efficiency check is hence to ensure the design of preliminary contract reflects the changes of financial variables, and the result of VFM is positive and maximum. 
Figure 6 Validation of efficiency improvement

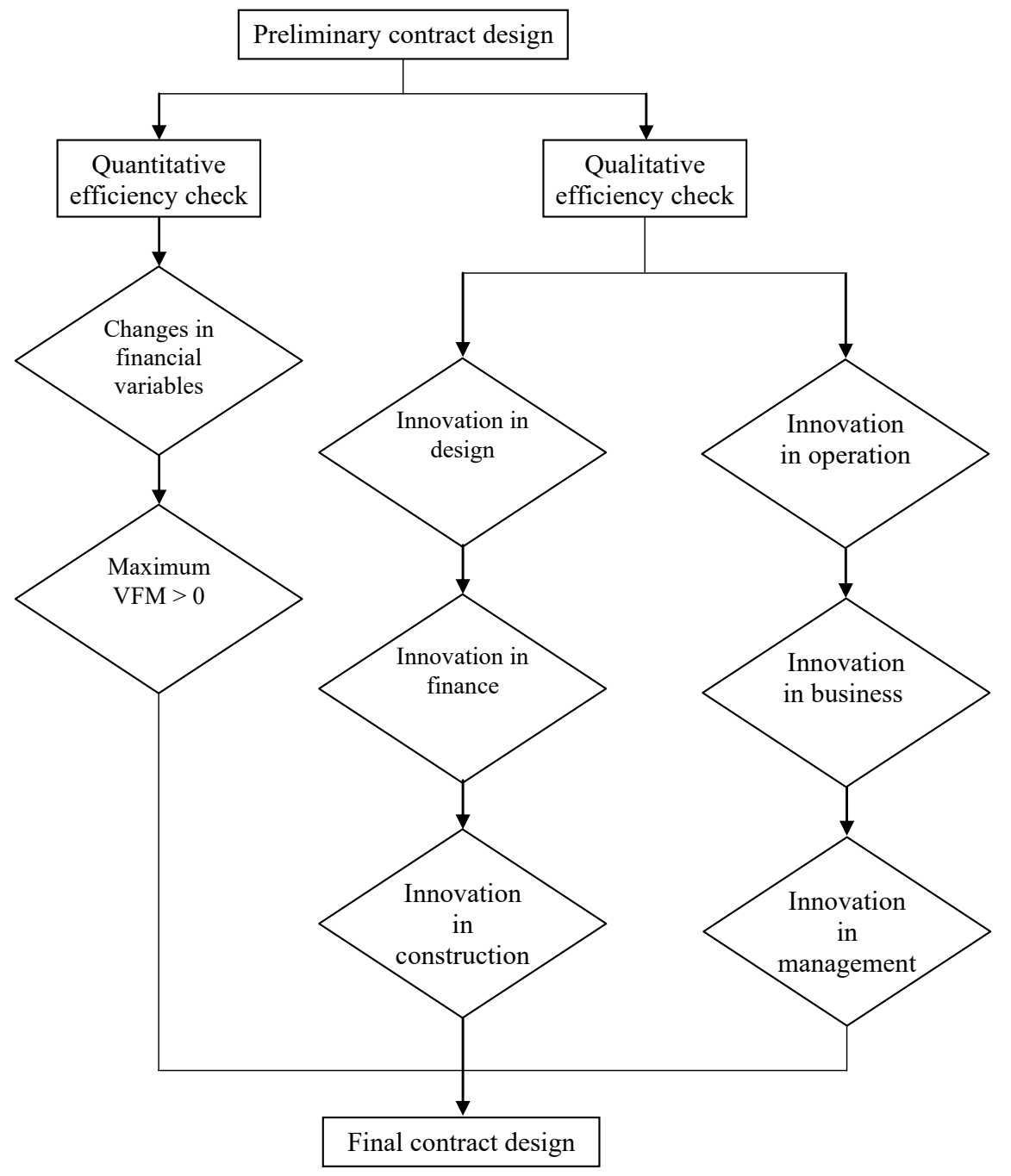

The purpose of qualitative efficiency check is to guarantee the delivery of each major task is more innovative than the traditional delivery mode. In urban rail projects, the tasks of design, finance, construction, operation, business and comprehensive management are particularly important. It is therefore imperative to check whether innovation designs are in place for these tasks.

\section{Conclusions}

This paper has looked at the procedural framework to determine the private involvement in urban rail PPP projects in China. The term of private involvement does not only refer to the share of investment by the private sector, but also denote a more comprehensive 
concept including responsibilities, obligations and risks undertaken, as well as resources and skills committed to a project by the private sector.

The proposed five-stage systematic framework firstly starts from the assessment whether to deliver the urban rail project via PPP. In the second and third stages, the public and private sectors determine the risk allocation and calculate the amount and plan of private investment under the conditions of organisational marketing strategies and policy and regulations. The output of the second and third stages is the preliminary design of concession contract defining the share of investment, responsibilities, obligations, risks undertaken, resources and skills committed to the project. In stages four and five, the requirements for public accountability and efficiency consideration are validated to ensure that private involvement in an urban rail project would not become a detrimental action to the public interests.

The findings add to the current knowledge base by summarising an appropriate and systematic procedural framework for the allocation of involvement in an urban rail PPP project. They are also beneficial for the industry practitioners as a management framework to determine the appropriateness of private involvement. The management implication is that designing a deal structure in a PPP project should consider all the procedures included in the framework.

Although the study scope is limited to urban rail projects in this paper, the findings can be generally applicable to other infrastructure sectors, especially for PPP projects where it is difficult for private investors to obtain a reasonable rate of investment return from the expected revenues. The procedural framework can also be generalised for countries where governments are legally allowed to develop government-pays PPPs. However, countries vary widely in how they document and give force to PPP frameworks. Readers need to be careful when using the proposed procedural framework to a different country.

Because of the indeterminate and heuristic nature in the research methodology, it is difficult to provide proof at this stage. To use the procedural framework for an application or for further research, readers need evidence to forecast the effectiveness of the framework and for translation into the new context. This is hence considered as one of the limitations of this paper. However, through multiple case-studies, one can accumulate supporting evidence, which can be a direction of future research.

\section{References}

Aken, J.E.V. (2004) 'Management research based on the paradigm of the design sciences: the quest for field-tested and grounded technological rules', Journal of Management Studies, Vol. 41, No. 2, pp.219-246.

Albalate, D., Bel, G. and Geddes, R.R. (2013) 'Recovery risk and labor costs in public-private partnerships: contractual choice in the US water industry', Local Government Studies, Vol. 39, No. 3, pp.332-351.

Beijing Municipal Commission of Development and Reform (2013) Implementation Plan of Pilot Projects for Introducing Social Capitals in the Infrastructure Development, in Chinese [online] http://www.bjpc.gov.cn/zt/wzz/201307/t6486566.htm (accessed 16 February 2015).

Chan, A.P.C., Lam, P.T.I., Chan, D.W.M., Cheung, E. and Ke, Y. (2009) 'Drivers for adopting public private partnerships-empirical comparison between China and Hong Kong special administrative region', Journal of Construction Engineering and Management, Vol. 135, No. 11, pp.1115-1124. 
Chan, A.P.C., Lam, P.T.I., Chan, D.W.M., Cheung, E. and Ke, Y. (2010) 'Potential obstacles to successful implementation of public-private partnerships in Beijing and the Hong Kong special administrative region', Journal of Management in Engineering, Vol. 26, No. 1, pp.30-40.

Chang, Z. (2013) 'Public-private partnerships in China: a case of the Beijing No. 4 Metro Line', Transport Policy, Vol. 30, pp.153-160 [online] https://www.sciencedirect.com/journal/ transport-policy/issues.

Chang, Z. (2014) 'Financing new metros - the Beijing metro financing sustainability study', Transport Policy, Vol. 32, pp.148-155 [online] https://www.sciencedirect.com/journal/ transport-policy/issues.

Cheng, Z., Ke, Y., Lin, J., Yang, Z. and Cai, J. (2016) 'Spatio-temporal dynamics of public-private partnership projects in China', International Journal of Project Management, Vol. 34, No. 7 , pp.1242-1251.

China Public-Private Partnerships Center (2016) Quarterly Report on the Project Library of the National PPP Integrated Information Platform (No. 4) http://www.cpppc.org/ en/Domestic/4286.jhtml (accessed 5 December 2016).

Cooper, D.F., Grey, S., Raymond, G. and Walker, P. (2005) Project Risk Management Guidelines: Managing Risk in Large Projects and Complex Procurements, John Wiley \& Sons, West Sussex, UK.

Cruz, C.O., Marques, R.C. and Cardoso, P. (2015) 'Empirical evidence for renegotiation of PPP contracts in the road sector', Journal of Legal Affairs and Dispute Resolution in Engineering and Construction, Vol. 7, No. 2, p.05014003.

de Jong, M., Mu, R., Stead, D., Ma, Y. and Xi, B. (2010) 'Introducing public-private partnerships for metropolitan subways in China: what is the evidence?', Journal of Transport Geography, Vol. 18, No. 2, pp.301-313.

Economist Intelligence Unit (2015) Evaluating the environment for public private partnerships in Asia-Pacific: The 2014 Infrascope, The Economist Intelligence Unit Ltd., Asian Development Bank, London, UK.

Forrer, J., Kee, J.E., Newcomer, K.E. and Boyer, E. (2010) 'Public-private partnerships and the public accountability question', Public Administration Review, Vol. 70, No. 3, pp.475-484.

Hayashi, Y. (1989) 'Issues in financing urban rail transit projects and value captures', Transportation Research Part A: General, Vol. 23, No. 1, pp.35-44.

IISD (2015) Public-Private Partnerships in China: On 2014 as a Landmark Year, with Past and Future Challenges, International Institute of Sustainable Development.

Infrastructure Australia (2008) National Public Private Partnerships Policy Framework, Infrastructure Australia, Canberra, Australia.

Irwin, T.C. (2007) Government Guarantees: Allocating and Valuing Risk in Privately Financed Infrastructure Projects, World Bank, Washington DC, USA.

Jasiukevičius, L. and Vasiliauskaite, A. (2012) 'Formation of optimal capital structure in private-public partnership', Economics and Management, Vol. 17, No. 4, pp.1275-1281.

Ke, Y., Ling, F.Y.Y. and Zou, P.X.W. (2015) 'Effects of contract strategy on interpersonal relations and project outcomes of public-sector construction contracts in Australia', Journal of Management in Engineering, Vol. 31, No. 4, p.04014062.

Ke, Y., Wang, S. and Chan, A.P.C. (2010a) 'Risk allocation in public-private partnership infrastructure projects: comparative study', Journal of Infrastructure Systems, Vol. 16, No. 4, pp.343-351.

Ke, Y., Wang, S. and Chan, A.P.C. (2011) 'Equitable risks allocation of projects inside China: analyses from Delphi survey studies', Chinese Management Studies, Vol. 5, No. 3, pp.298-310.

Ke, Y., Wang, S. and Chan, A.P.C. (2013) 'Risk misallocation in public-private partnership projects in China', International Public Management Journal, Vol. 16, No. 3, pp.438-460. 
Ke, Y., Wang, S., Chan, A.P.C. and Cheung, E. (2009) 'Research trend of public-private partnership in construction journals', Journal of Construction Engineering and Management, Vol. 135, No. 10, pp.1076-1086.

Ke, Y., Wang, S., Chan, A.P.C. and Lam, P.T.I. (2010b) 'Preferred risk allocation in China's public-private partnership (PPP) projects', International Journal of Project Management, Vol. 28, No. 5, pp.482-492.

Lam, K.C., Wang, D., Lee, P.T. and Tsang, Y.T. (2007) 'Modelling risk allocation decision in construction contracts', International Journal of Project Management, Vol. 25, No. 5, pp.485-493.

Liu, L. and Pradelli, J. (2012) Financing Infrastructure and Monitoring Fiscal Risks at the Subnational Level, Policy Research Working Paper 6069, The World Bank.

Michalski-Karl, R., Pernsteiner, S.M. and Schaffhauser-Linzatti, M.M. (2009) 'Signaling public private partnership activities: reporting behavior within annual reports', International Advances in Economic Research, Vol. 15, No. 2, pp.178-185.

Peru (2008) Legislative Decree No. 1012, Lima, Republic of Peru.

Roumboutsos, A., Liu, T. and Wilkinson, S. (2013) 'Can the pilot public-private partnerships project be applied in future urban rail development? A case study of Beijing Metro Line 4 project', Built Environment Project and Asset Management, Vol. 3, No. 2, pp.250-263.

Sachs, T., Tiong, R.L.K. and Wang, S.Q. (2007) 'Analysis of political risks and opportunities in public private partnerships in China and selected Asian countries - survey results', Chinese Management Studies, Vol. 1, No. 2, pp.126-148.

Sharma, D.K., Cui, Q., Chen, L. and Lindly, J.K. (2010) 'Balancing private and public interests in public-private partnership contracts through optimization of equity capital structure', Transportation Research Record: Journal of the Transportation Research Board, Vol. 2151, No. 1, pp.60-66.

Si, B., Fu, L., Liu, J., Shiravi, S. and Gao, Z. (2016) 'A multi-class transit assignment model for estimating transit passenger flows - a case study of Beijing subway network', Journal of Advanced Transportation, Vol. 50, No. 1, pp.50-68.

Simpson, B.J. (1990) Urban Rail Transit Costs and Funding, Transport and Road Research Laboratory, Berkshire, UK.

Wang, B. (2014) Keynote Speech on the Training Session of PPP on 17 March 2014, http://jrs.mof.gov.cn/ppp/tpbdppp/201410/t20141031_1155420.html (accessed 2 November 2015).

Wilmoth, D. (1990) 'Urban infrastructure finance issues in Australia: a review in the context of international experience', Urban Policy and Research, Vol. 8, No. 4, pp.159-168.

Xinhuanet (2016) The 13th Five-Year Plan of P.R. China, in Chinese [online] http://news.xinhuanet.com/politics/2016lh/2016-03/17/c_1118366322.htm (accessed 11 November 2016).

Yuan, J., Skibniewski, M.J., Li, Q. and Shan, J. (2010) 'The driving factors of China's public-private partnership projects in metropolitan transportation systems: public sector's viewpoint', Journal of Civil Engineering and Management, Vol. 16, No. 1, pp.5-18.

Zhang, S., Chan, A.P.C., Feng, Y., Duan, H. and Ke, Y. (2016) 'Critical review on PPP research a search from the Chinese and international journals', International Journal of Project Management, Vol. 34, No. 4, pp.597-612.

Zhang, X. (2005) 'Financial viability analysis and capital structure optimization in privatized public infrastructure projects', Journal of Construction Engineering and Management, Vol. 131, No. 6, pp.656-668.

Zhang, X. and Chen, S. (2013) 'A systematic framework for infrastructure development through public private partnerships', IATSS research, Vol. 36, No. 2, pp.88-97. 